\title{
IMPLEMENTASI PENYELENGGARAAN PELATIHAN FOTOGRAFI DI SEKOLAH TINGGI KEGURUAN ILMU PENDIDIKAN SILIWANGI BANDUNG
}

\author{
${ }^{1}$ Nandang Rukanda, 2Prita Kartika \\ 1,2 IKIP Siliwangi \\ 1'nandangsae@gmail.com, ${ }^{2}$ pritak2@gmail.com
}

\begin{abstract}
ABSTRAK
Pelatihan Profesi Bidang Fotografi merupakan salah satu bentuk pendidikan yang diselenggarakan melalui jalur pendidikan luar sekolah (PLS) dengan mengutamakan pembekalan keterampilan guna meningkatkan kecakapan hidup bagi masyarakat, yang berguna untuk kepentingan diri pribadinya maupun bisa di manfaatkan bagi kepentingan dunia kerja dan profesinya. Disekitar STKIP Siliwangi terdapat banyak warga masyarakat yang berminat dan membutuhkan pelatihan fotografi termasuk dari kalangan para pelajar dan mahasiswa. Penelitian ini dilakukan terhadap Pelatihan fotografi yang dilaksanakan di STKIP Siliwangi Bandung dalam rangka mewujudkan amanah pengabdian masyarakat lembaga perguruan tinggi sebagai salah satu wujud dalam pelaksanaan Tridharma Perguruan Tinggi. Metode penelitian mempergunakan metode kualitatif, berdasar pertimbangan atas kedalaman hasil penelitian yang berhubungan makna dari pada generalisasi, sehingga kekuatan penenitian akan peneliti maksimalkan dalam hal observasi dan wawancara, baik berkenaan dengan relevansi isi pertanyaan dengan kajian, maupun berhubungan dengan ketepatan terhadap respondennya. Teknik pengumpulan data dengan observasi, wawancara dan studi dokumentasi dan Analisis data dilakukan peneliti dengan memeriksa, mempelajari, membandingkan data yang ada dan membuat interpretasi yang diperlukan. Penelitian ini secara umum telah mencapai tujuannya yaitu memperoleh gambaran dari pelatihan fotografi yang diselenggarakan di STKIP Siliwangi Bandung, sebagai upaya mewujudkan salah satu bagian Tri Darma Perguruan Tinggi berkenaan dengan pengabdian kepada masyarakat. Saran dan rekomendasi ditujukan terhadap STKIP Siliwangi Bandung sebagai penyelenggara program untuk meningkatkan proses kesiapannya dalam penyelenggaraan program, para instruktur pelatihan untuk memaksimalkan pelaksanaan pembelajarannya, alumni pelatihan untuk memaksimalkan aplikasi pengamalan dari yang diperolehnya, dan bagi masyarakat untuk selalu mendukung kegiatan pelatihan dalam rangka pemberdayaan masyarakat.
\end{abstract}

Kata kunci : Pelatihan, Fotografi dan Pemberdayaan Masyarakat.

PENDAHULUAN

\section{A. Latar Belakang Masalah}

Program-program pemerintah dibidang Pendidikan Non Formal (PNF) yang semakin hari semakin dipacu untuk tumbuh dan berkembang dengan mengadakan pelatihan-pelatihan di berbagai bidang keterampilan merupakan usaha untuk membuka seluas-luasnya kesempatan belajar bagi masyarakat yang kurang beruntung yang tidak dapat melanjutkan ke jenjang 
sekolah lebih tinggi / anak-anak dropped-out (putus sekoah).

Kenyataan dilapangan menunjukkan bahwasanya keterampilan dibidang Fotografi mempunyai prospek yang marketable dan dibutuhkan semua kalangan masyarakat, hal ini berkaitan erat dengan fungsi fotografi sebagai media pencetak dokumentasi penting yang dapat dijadikan bukti bagi berbagai kejadian dan aktivitas, baik dalam lembaga, perkumpulan, organisasi ataupun yang lainnya, pada Dinas Pemerintah, Kantor swasta, Perguruan Tinggi dan lain-lain.

Pelatihan Profesi Bidang Fotografi merupakan salah satu bentuk pendidikan yang diselenggarakan melalui jalur pendidikan luar sekolah (PLS) dengan mengutamakan pembekalan keterampilan guna meningkatkan kecakapan hidup bagi masyarakat, yang berguna untuk kepentingan diri pribadinya maupun bisa di manfaatkan bagi kepentingan dunia kerja dan profesinya.

Berdasarkan hasil identifikasi calon peserta didik pelatihan fotografi bahwa disekitar STKIP Siliwangi terdapat banyak warga masyarakat yang berminat dan membutuhkan pelatihan fotografi termasuk dari kalangan para pelajar dan mahasiswa. .

\section{B. Rumusan Masalah}

Berdasarkan latar belakang dan identifikasi masalah tersebut diatas, penulis merumuskan masalah pokok dalam penelitiaannya yaitu:

1. Bagaimana perencanan pelatihan fotografi di STKIP Siliwangi Bandung?

2. Bagaimana strategi pelatihan fotografi di STKIP Siliwangi Bandung?
3. Bagaimanakah hasil pelatihan fotografi yang dilaksanakan di STKIP Siliwangi Bandung?

4. Bagaimanakah tindak lanjut pelatihan fotografi yang dilaksanakan di STKIP Siliwangi Bandung?

\section{Tujuan Penelitian}

1. Untuk mengetahui bagaimana proses perencanan pelatihan fotografi di STKIP Siliwangi Bandung.

2. Untuk mengetahui bagaimana strategi pelatihan fotografi di STKIP Siliwangi Bandung.

3. Untuk mengetahui bagaimanakah hasil pelatihan fotografi yang dilaksanakan di STKIP Siliwangi Bandung.

4. Untuk mengetahui bagaimanakah tindak lanjut pelatihan fotografi yang dilaksanakan di STKIP Siliwangi Bandung

\section{Manfaat Penelitian}

1. Manfaat Teoritis

a. Penelitian ini bermanfaat sebagai aplikasi keilmuan teori-teori PLS dalam kajiannya terhadap program pelatihan yang terdapat dimasyarakat.

b. Penelitian ini juga bermanfaat untuk mengembangkan teori-teori PLS yang telah ada terutama bidang kajian pelatihan, karena dimungkinkan hasil pengkajian penelitian ini bisa menunjukkan fakta yang terus berkembang dari kajian-kajian sebelumnya.

\section{Manfaat Praktis}

a. Dalam rangka membantu mengkaji perencanaan dan strategi pelaksanaan pelatihan secara umum dan pelatihan fotografi di STKIP Siliwangi Bandung secara khusus.

b. Sebagai acuan dasar penentuan kebijakan program pelatihan bagi STKIP Siliwangi Bandung. 
c. Upaya praktis penerapan solusi pemecahan masalah ketidakberdayaan masyarakat golongan ekonomi lemah

\section{METODE PENELITIAN}

\section{A. Metode Penelitian}

Metode penelitian ini dalam pengkajiannya mempergunakan metode kualitatif. Hal ini berdasar pertimbangan atas kedalaman hasil penelitian yang berhubungan makna dari pada generalisasi, sehingga kekuatan penenitian akan peneliti maksimalkan dalam hal observasi dan wawancara, baik berkenaan dengan relevansi isi pertanyaan dengan kajian, maupun berhubungan dengan ketepatan terhadap respondennya.

Dalam pelaksanaannya dilapangan, peneliti menyatu dengan situasi yang diteliti, hal ini dilakukan mengingat bahwa peristiwa-perilaku manusia dipengaruhi oleh "setting" di mana keadaan itu terjadi, sehingga perilaku manusia itu tidak dapat dipahami tanpa memahami bingkai yang didalamnya manusia menginterpretasikan pemikiran, perasaan, dan tindakantindakannya.

\section{B. Metode Pengumpulan Data}

Teknik pengumpulan data dalam penelitian ini mempergunakan tiga teknik pengumpulan data yang populer dalam penelitian kualitatif, yaitu observasi, wawancara dan studi dokumentasi, dengan penjelasan dan pertimbangan sebgai berikut :

\section{a. Observasi}

Observasi dilakukan, dimana peneliti melakukan pengamatan dilapangan, hal ini dimaksudkan agar peneliti memperoleh gambaran realistik perilaku atau kejadian, untuk menjawab pertanyaan, untuk membantu mengerti perilaku objek penelitian, dan untuk evaluasi yaitu melakukan pengukuran terhadap aspek tertentu melakukan umpan balik terhadap pengukuran tersebut.

Adapun Alat yang bisa digunakan dalam pengamatan adalah lembar pengamatan, ceklist dan catatan kejadian.

\section{b. Wawancara}

Wawancara merupakan proses komunikasi yang sangat menentukan dalam proses penelitian ini. Dengan wawancara data yang diperoleh akan lebih mendalam, karena mampu menggali pemikiran atau pendapat secara detail. Oleh karena itu dalam pelaksanaan wawancara peneliti akan berusaha sebaik mungkin dalam berkomunikasi dengan responden dan bersikap netral.

Secara garis besar pedoman wawancara yang akan dilakukan peneliti adalah dengan dua hal, yaitu:

1) Pedoman wawancara tidak terstruktur, yaitu pedoman wawancara yang hanya memuat garis besar yang akan ditanyakan untuk mengungkap pendapat responden secara apa adanya dan spontan.

2) Pedoman wawancara terstruktur, yaitu pedoman wawancara yang disusun secara terperinci, yang mengacu pada susunan angket yang akan dibuat.

\section{c. Studi Dokumentasi}

Melalui studi dokumentasi dilakukan pengamatan dan penganalisaan terhadap dokumen-dokumen yang dibuat oleh subjek penelitian atau oleh orang lain yang relevan dengannya.

\section{Metode Analisis Data}

Selanjutkan dilakukan analisa data 
dengan mempergunakan metode deskripsi kualitatif secara mendalam, yang digunakan untuk membantu peneliti mengetahui kedalaman hasil penelitian. evaluasi sangat diperlukan untuk mengetahui sejauh mana keberhasilan dapat dicapai secara maksimal, baik pada proses kegiatan itu sendiri, maupun tujuan akhir yang diharapkan. Kegiatan analisa dilakukan untuk memperoleh hasil pengukuran yang valid dan reliable penelitian dimaksud.

Analisis data dilakukan peneliti dengan memeriksa, mempelajari, membandingkan data yang ada dan membuat interpretasi yang diperlukan. Selain itu, analisis data juga digunakan dengan mengindentifikasi ada tidaknya masalah. Kalau ada masalah maka dirumuskan dengan jelas dan benar, sehingga diketahui gambaran terhadap makna dari indikator-indikator yang ada. Manfaat analisis data ini adalah sebagai bahan masukan untuk pengambilan keputusan, perencanaan, pemantauan, pengawasan, dan penyusunan laporan.

\section{HASIL PENELITIAN DAN PEMBAHASAN}

\section{A. Gambaran Umum Objek Penelitian 1. STKIP Siliwangi Bandung}

STKIP Siliwangi Bandung berdiri pada 11 Maret 1986 sebagai pelaksana Visi dan Misi Kodam III/Siliwangi dalam mewujudkan bakti dan balas budi Siliwangi terhadap masyarakat Jawa Barat dan Banten.

STKIP Siliwangi mendapatkan Nilai Peringkat Akreditasi B pada Akreditasi Institusi Perguruan Tinggi (AIPT) dari Badan Akreditasi Nasional Perguruan Tinggi (BAN-PT). Hal ini tercantum pada SK yang dikeluarkan BAN-PT pada tanggal 20 Mei 2016 dengan
Nomor 0553/SK/BAN-PT/Akred/PT/V /2016.

Pada tanggal 10 Oktober 1987 ke Empat Program Studi tersebut mendapat Status Terdaftar berdasarkan SK Mendikbud RI Nomor : 0631 Tahun 1987, dan hingga saat ini, Rincian Akreditasi Program Studi yang telah dilakukan oleh BAN-PT adalah sebagai berikut:

1) Magister Pendidikan Luar Sekolah: No. 507/SK/BANPT/Akred/M/VI/2015

2) Magister Pendidikan Matematika: No. 1152/SK/BANPT/Akred/M/XI/2015

3) Pendidikan Luar Sekolah: No. 1122/SK/BANPT/Akred/S/X/2015

4) Pendidikan Bahasa Inggris: No. 773/SK/BAN-PT/Akred/S/VII/2015

5) Pendidikan Bahasa dan Sastra Indonesia: No. 387/SK/BANPT/Akred/S/X / 2014

6) Pendidikan Matematika: No. 377/SK/BAN-PT/Akred/S/IX/2014

Kegiatan pengabdian masyarakat merupakan kegiatan penting bagi STKIP Siliwangi Bandung sebagai salah satu wujud dalam pelaksanaan Tridharma Perguruan Tinggi. Melalui kegiatan pengabdian masyarakat diharapkan para dosen dan civitas akademika dapat mengembangkan dan menerapkan ilmu pengetahuan dan teknologi khususnya bidang keguruan dan ilmu pendidikan.

Lembaga yang ditunjuk STKIP Siliwangi untuk menaungi aktivitas penelitian dan pengabdian pada masyarakat adalah UPT - P2M, yang visinya adalah menjadi lembaga penelitian dan pengabdian masyarakat berstandar mutu internasional, dan misinya adalah (1) meningkatkan dan mengembangkan kualitas penelitian dan pengabdian 
kepada masyarakat dalam bidang pendidikan formal, nonformal, dan informal. (2) meningkatkan dan mengembangkan penelitian dan pengabdian kepada masyarakat yang memiliki relevansi terhadap peningkatan mutu pendidikan untuk mencapai visi lembaga the leader of learning innovation. (3) meningkatkan dan mengembangkan penelitian dan pengabdian kepada masyarakat yang memiliki relevansi terhadap peningkatan mutu pendidikan untuk mencapai visi lembaga the leader of learning innovation. (4) meningkatkan dan mengembangkan penelitian dan pengabdian kepada masyarakat yang memiliki relevansi terhadap peningkatan mutu pendidikan untuk mencapai visi lembaga the leader of learning innovation. (5) meningkatkan dan mengembangkan publikasi hasil penelitian dan pengabdian kepada masyarakat melalui jurnal ilmiah bertaraf internasional.

meningkatkan dan mengembangkan kualitas pengabdian kepada masyarakat Jawa Barat sebagai wujud bakti Kodam III/Siliwangi. (7) meningkatkan dan mengembangkan perolehan HKI (Hak Kekayaan Intelektual).

\section{Masyarakat Sekitar STKIP Siliwangi Bandung}

Pertumbuhan penduduk sekitar STKIP Siliwangi cukup tinggi, terutama yang diakibatkan adanya urbanisasi dan pendatang. Secara umum jenis kegiatannya banyak berhubungan dengan perumahan, pendidikan dan pelayanan umum. Profesinya banyak berhubungan dengan perdagangan dan jasa, pegawai pemerintahan dan pendidikan.

Upaya penataan penduduk dilaksanakan sebagai perubahan status pemerintahan Pemkot Cimahi memprioritaskan beberapa program yang diantaranya, penyusunan perencanaan umum berupa RTRW, Poldas, Properda dan Renstan. Selain itu juga tidak kalah pentinggya upaya peningkatan pelayanan pada masyarakat dari segi aspek fisik, ekonomi, sosial dan budaya.

\section{B. Deskripsi Hasil Penelitian}

Kegiatan pelatihan fotografi dilakukan dalam rangka mewujudkan amanah pengabdian masyarakat dari lembaga perguruan tinggi STKIP Siliwangi Bandung sebagai salah satu wujud dalam pelaksanaan Tridharma Perguruan Tinggi. Melalui kegiatan pengabdian masyarakat diharapkan para dosen dan civitas akademika dapat mengembangkan dan menerapkan ilmu pengetahuan dan teknologi khususnya bidang keguruan dan ilmu pendidikan.

Selanjutnya kegiatan pengabdian masyarakat ini ditujukan dalam rangka meningkatkan kemampuan para dosen dalam aktivitas riil-nya dimasyarakat. Dengan demikian, kegiatan pengabdian masyarakat yang dilakukan di STKIP Siliwangi pada akhirnya dapat mewujudkan budaya harmonis lembaga pendidikan tinggi STKIP Siliwangi Bandung dengan lingkungannya.

Ide perencanaan pelatihan fotografi timbul dari inisiatif dosen Program Studi Pendidikan Luar Sekolah yang dikemukakaan pada saat rapat persiapan program STKIP mengajar melalui penyelenggaraan bimbingan belajar bagi pelajar sekolah formal untuk usia Sekolah Dasar, Sekolah Menengah Tingkat Pertama dan Sekolah Menengah Tingkat Atas.

Pelatihan fotografi yang dilaksanakan di STKIP Siliwangi Bandung pada Januari Maret 2016. Pelatihan fotografi ini sesungguhnya dilakukan bertepatan 
dengan waktu liburan mahasiswa dilembaganya, sehingga terdapat keluangan waktu bagi dosen-dosen didalamnya.

Pelaksanaan kegiatan pelatihan fotografi sesungguhnya dilakukan satu kali dalam seminggu, yakni setiap hari Sabtu, dan dilaksanakan jam 11.00 13.00 WIB., setelah sebelumnya jam 08.00 - 11.00 WIB dilakukan program bimbingan belajar. Tempat pelatihan adalah dikampus STKIP Siliwangi dengan mempergunakan fasilitas ruangan aula, ruang kelas, dan halaman sekitarnya.

Para peserta yang mengikuti pelatihan fotografi ini adalah para pelajar usia sekolah, mulai dari Sekolah Dasar (SD) sampai dengan Sekolah Menengah Tingkat Atas (SMU).

Peserta pelatihan fotografi teramati dipertemuan-pertemuan awal jumlahnya melebihi seratus orang, namun setelah dipertemuan-pertemuan akhir semakin menurun hingga yang tercatat hanya enam orang untuk kelompok umur kelas Sekolah Dasar.

Adapun intruktur yang membina pada pelatihan fotografi adalah para dosen Program Studi Pendidikan Luar Sekolah STKIP Siliwangi ditambah seorang alumninya yang dalam profesi kesehariannya bergerak sebagai fotografer professional.

Dalam mengikuti pelatihan fotografi para peserta tidak dibebankan mengeluarkan biaya melainkan seluruhnya berada pada tanggungan lembaga STKIP Siliwangi. Demikian pula mereka tidak dibebankan untuk membawa alat fotografi karena sudah disediakan, hanya dianjurkan untuk membawa alat tulis an sich.
Pelatihan fotografi dilaksanakan dalam 10 - 12 kali pertemuan sehingga tercatat dilakukan dalam waktu 3 bulan, Januari - Maret 2016. Setelah pertemuan berakhir maka seiring dengan itu pula secara otomatis para peserta selesai mengikuti pelatihan dan mereka kembali kepada lingkungannya.

\section{Analisis Hasil Penelitian \\ 1. Perencanaan Program Pelatihan Keterampilan Fotografi}

Rencana program kerja berasal dari para dosen PLS dengan memperhatikan kondisi persoalan dan kebutuhan yang ada di masyarakat yakni pentingnya suplemen dan komplemen terhadap para pelajar sekolah selain mempunyai ilmu pengetahuan formal, juga dibekali keterampilan terapan untuk bekal mempertahankan kehidupan yang semakin kompetitif dan memasuki dunia kerja.

Setelah direkomendasikan penyelenggaraan program program pelatihan fotografi maka selanjutnya ditindaklanjuti dengan melakukan tahapan kegiatan berikut :

1) Persiapan dan Penentuan Tempat Pelatihan.

2) Penentuan dan pengaturan alat-alat yang akan dipergunakan pelatihan.

3) Penyusunan materi pelatihan.

4) Rekruitmen peserta pelatihan.

5) Target Program Pelatihan.

\section{Strategi Pelaksanaan Pelatihan Keterampilan Fotografi.}

Strategi yang digunakan sumber belajar dalam program pelatihan keterampilan fotografi adalah dengan menggunakan pendekatan andragogi atau pendekatan pembelajaran partisipasif, dengan memberikan kesempatan seluasluasnya kepada peserta didik untuk terlibat dalam proses pelaksanaan 
pelatihan.

Sesungguhnya, motivasi para peserta pelatihan pada awalnya cukup tinggi hal itu ditenggarai rasa kepenasaranan mereka terhadap dunia fotografi dan harapan mereka mendapatkan sesuatu selain hanya sekedar ilmu. Mereka berharap pelaksanaan pelatihan berada pada situasi yang kondusif berkenaan dengan waktu, tempat dan alat penunjang lainnya. Harapan tersebut ternyata tidak didapatkan secara keseluruhan maka menjadikan partisipasi mereka terus menurun terbukti dengan jumlah kehadiran dari pererta yang semakin sedikit.

Metode yang digunakan dalam pelatihan keterampilan fotografi adalah metode andividual dan metode kelompok, pelaksanaannya disesuaikan dengan kebutuhan dilapangan. Seluruh warga belajar mendapat materi pelatihan yang bersifat teori, dan pada saat praktek.

Teknik pelatihan yang digunakan dalam pelatihan keterampilan fotografi adalah : (1) metode ceramah, (2) metode curah pendapat, (3) metode diskusi, (4) metode demonstrasi, (5) metode simulasi, (6) metode penugasan (drill), dan (7) metode kerja kelompok.

Media yang digunakan dalam pelatihan keterampilan fotografi adalah : (1) buku-buku sumber tentang fotografi;
(2) gambar-gambar fotografi; (3) komponen-komponen asesoris fotografi; (4) Laptop; (5) LCD, dan media lainnya yang digunakan untuk memperlancar proses pembelajaran dalam pelatihan.

\section{Hasil Pelatihan Keterampilan Fotografi.}

Secara keseluruhan warga belajar Pelatihan Keterampilan Fotografi telah menyelesaikan pelatihan dengan tuntas, sesuai dengan jangka waktu yang telah ditetapkan, yakni selama tiga bulan dalam 12 kali pertemuan dan dilaksanakan dua jam setiap harinya. Pelatihan dilaksanakan jam 11.00 12.00 WIB, bertempat di kampus STKIP Siliwangi Bandung.

Dari hasil pengolahan data ditunjukan bahwa seluruh warga belajar yang mengikuti pelatihan keterampilan fotografi tersebut lulus semua secara otomatis. Dengan begitu warga belajar telah memperoleh pengetahuan dan keterampilan fotografi serta etika bersikap sebagai seorang fotografer.

Dari hasil analisis data selanjutnya, menunjukan pengaruh hasil pelatihan fotografi ini terhadap ranah kognitif, afektif dan psikomotor alumninya dapat diuraikan sebagai berikut:

Tabel 4.1

Relevansi Keberhasilan Lulusan Program Pelatihan Keterampilan Fotografi terhadap Ranah Kognitif, Afektif dan Psikomotor Alumni

\begin{tabular}{clc}
\hline Aspek yang & \multicolumn{2}{c}{ Keadaan Warga Belajar } \\
\cline { 2 - 3 } Dinilai & \multicolumn{1}{c}{$\begin{array}{c}\text { Sebelum mengikuti } \\
\text { proses pelatihan }\end{array}$} & $\begin{array}{c}\text { Sesudah mengikuti } \\
\text { proses pelatihan }\end{array}$ \\
\hline A. Aspek Kognitif & 1. Tidak memiliki & 1. Memiliki pengetahuan \\
& pengetahuan di bidang & di bidang fotografi \\
& fotografi & 2. Memiliki pengetahuan \\
& 2. Tidak memiliki & tentang etika profesi \\
& pengetahuan tentang & fotografer.
\end{tabular}




\begin{tabular}{|c|c|}
\hline $\begin{array}{c}\text { Aspek yang } \\
\text { Dinilai }\end{array}$ & $\begin{array}{c}\text { Keadaan } \\
\begin{array}{c}\text { Sebelum mengikuti } \\
\text { proses pelatihan }\end{array}\end{array}$ \\
\hline & etika profesi fotografer. \\
\hline B. Aspek Afektif & $\begin{array}{l}\text { 1. Kurang percaya diri } \\
\text { dalam pergaulan } \\
\text { 2. Kurang disiplin dalam } \\
\text { menghargai waktu } \\
\text { 3. Tidak } \\
\text { mempertimbangkan } \\
\text { tanggung jawab dalam } \\
\text { kehidupan }\end{array}$ \\
\hline $\begin{array}{l}\text { C. Aspek } \\
\text { Psikomotor }\end{array}$ & $\begin{array}{l}\text { 1. Tidak terampil dalam } \\
\text { bidang fotografi }\end{array}$ \\
\hline
\end{tabular}

\section{Tindak lanjut Pasca Pelatihan Keterampilan Fotografi.}

Kegiatan pelatihan fotografi dilakukan dalam rangka mewujudkan amanah pengabdian masyarakat dari lembaga perguruan tinggi STKIP Siliwangi Bandung sebagai salah satu wujud dalam pelaksanaan Tridharma Perguruan Tinggi. Melalui kegiatan pengabdian masyarakat diharapkan para dosen dan civitas akademika dapat mengembangkan dan menerapkan ilmu pengetahuan dan teknologi khususnya bidang keguruan dan ilmu pendidikan.

Berdasarkan penjelasan diatas maka seyogianya program pelatihan ini adalah program yang akan dilakukan secara berkelanjutan, karena merupakan program yang tentunya disusun untuk suatu kegiatan rutin agenda Lembaga Perguruan Tinggi STKIP Siliwangi.

Dengan demikian maka layaknya program pelaksanaan pelatihan fotografi ini dievaluasi sedemikian rupa oleh Lembaga Perguruan Tinggi STKIP Siliwangi untuk bisa menilai sejauhmana tingkat kebermanfaatan, efektivitas dan efisiensinya, sehingga pada keadaan selanjutnya dapat
1. Timbul rasa percaya diri dalam pergaulan

2. Menjadi orang yang disiplin dalam menghargai waktu

3. Menjadi orang yang bertanggung jawab dalam kehidupan

1. Menjadi terampil dalam bidang fotografi

ditentukan keputusan apakah program ini akan dipertahankan, dilanjutkan atau justru dihentikan dan diganti dengan kegiatan yang lain.

\section{Pembahasan}

\section{Perencanaan Program Pelatihan Keterampilan Fotografi}

Berdasarkan hasil penganalisaan, rencana pelatihan fotografi di STKIP Siliwangi adalah tepat dilakukan dengan mekanisme yang relevan. Hal ini diantaranya karena dilakukan oleh mereka yang berprofesi sebagai pengembang keilmuan dalam bidang pendidikan luar sekolah, berkenaan konsep pelatihan dan pemberdaya masyarakat.

Tahapan perencanaan yang ditempuh yakni (1) persiapan dan penentuan tempat pelatihan, (2) penentuan dan pengaturan alat-alat yang akan dipergunakan pelatihan, (3) penyusunan materi pelatihan, (4) rekruitmen peserta pelatihan, dan (5) target program pelatihan, adalah sudah sesuai dengan sistematika kerja kajian ilmiah, dengan demikian maka akan memudahkan pelaksanaan kedepannya.

\section{Strategi Pelaksanaan Program Pelatihan Keterampilan Fotografi}


Pelaksanaan adalah segala aktivitas yang berkenaan dengan penyelenggaraan pelatihan terutama proses pembelajaran dalam pelatihan meliputi tujuan, materi, metode, teknik, media, kegiatan pembelajaran dan evaluasi serta sumber belajar dan warga belajar. Pelaksanaan suatu kegiatan pembelajaran, termasuk pelatihan merupakan proses transformasi pengetahuan, sikap dan keterampilan dari sumber belajar kepada warga belajar. Pelaksanaan Pelatihan Keterampilan Fotografi ditetapkan sesuai dengan tujuannya, yaitu memberikan pengetahuan, keterampilan di bidang fotografi dan sikap kemandirian usaha atau kewirausahaan yang mendukung pengembangan usaha warga belajar. Secara nyata diketahui bahwa pelaksanaan penyelenggaraan dilakukan secara efektif dan efisien, karena sesuai dengan waktu yang dijadwalkan dan menghasilkan lulusan yang diharapkan.

Hasil penelitian di lapangan menunjukkan bahwa pelaksanakan pelatihan fotografi di STKIP Siliwangi merupakan proses interaksi edukatif antara peserta didik dengan komponenkomponen pembelajaran lainnya seperti masukan sarana, masukan lingkungan, masukan mentah, dan masukan lain.

\section{Hasil dan Pengaruh Program Pelatihan Keterampilan Fotografi}

Dari hasil pengamatan diketahui bahwa para alumni pelatihan berhasil memiliki pengetahuan dan keterampilan dibidang fotografi serta sikap sikap etika sebagai seorang fotografer.

Gambaran hasil penelitian yang dikemukakan responden itu, memperlihatkan bahwa hasil pelatihan fotografi ini memberikan makna yang positif tehadap perilaku kehidupan mereka, khususnya pada peningkatan pengetahuan dan keterampilan dibidang fotografi serta pengembangan sikap etika fotografer yang akhirnya bermanfaat dalam pengembangan kehidupannya.

Hasil pelatihan adalah perubahan tingkah laku yang berupa peningkatan pengetahuan, keterampilan dan perkembangan sikap seseorang melalui proses belajar atau pelatihan dan harus dapat dipergunakan untuk meningkatkan penampilan dirinya dalam hidup atau kehidupan. Secara umum mamfaat pelatihan atau pendidikan yang berorientasi kepada pelatihan fotografi bagi warga belajar adalah memberikan bekal pengetahuan, keterampilan dan dan sikap etika profesi untuk menghadapi dan memecahkan masalah hidup dan kehidupan baik sebagai pribadi dan warga masyarakat yang mandiri.

\section{Tindak lanjut Pasca Pelatihan Keterampilan Fotografi.}

Kegiatan pelatihan fotografi yang dilakukan dalam rangka mewujudkan amanah pengabdian masyarakat dari lembaga perguruan tinggi STKIP Siliwangi Bandung sebagai salah satu wujud dalam pelaksanaan Tridharma Perguruan Tinggi, maka dapat dipahami bahwa seyogianya program pelatihan ini adalah program yang akan dilakukan secara berkelanjutan, karena merupakan program yang tentunya disusun untuk suatu kegiatan rutin agenda Lembaga Perguruan Tinggi STKIP Siliwangi.

Dengan demikian maka layaknya program pelatihan fotografi ini bermanfaat bagi Lembaga Perguruan Tinggi STKIP Siliwangi untuk lebih mempopulerkan dan memfamiliarkan lembaganya ditengah-tengah 
masyarakat yang luas. Juga bermanfaat untuk meningkatkan kebermanfaatan, efektivitas dan efisiensi keberadaannya ditengah-tengah masyarakat, sehingga pada keadaan selanjutnya akan lebih dikenal dimasyarakat dengan meningkatnya kuantitas jumlah mahasiswa, dan mendapat kepercayaan penuh dari masyarakat, koordinator perguruan tinggi swasta (Kopertis) dan Kementrian Pendidikan dan Kebudayaan Negara Republik Indonesia.

\section{KESIMPULAN DAN SARAN}

\section{A. Kesimpulan}

Penelitian ini secara umum telah mencapai tujuannya yaitu memperoleh gambaran dari pelatihan fotografi yang diselenggarakan di STKIP Siliwangi Bandung, sebagai upaya mewujudkan salah satu bagian Tri Darma Perguruan Tinggi berkenaan dengan pengabdian kepada masyarakat.

PLS sebagai proses pemberdayaan mengandung makna bahwa programprogram pendidikan ini harus ditunjukan untuk mendidik masyarakat agar mampu mendidik diri mereka sendiri atau membantu masyarakat agar mampu menbantu diri mereka sendiri dalam rangka menciptakan masyarakat yang mandiri, berswadaya, dan berdaya.

1. Perencanaan Program Pelatihan Keterampilan Fotografi adalah tepat dilakukan dengan mekanisme yang relevan, karena konsep dibuat oleh orang berprofesi sebagai pengembang keilmuan dalam bidang pendidikan luar sekolah, berkenaan konsep pelatihan dan pemberdaya masyarakat.

2. Strategi Pelaksanaan Program Pelatihan Keterampilan Fotografi meliputi menyelarasan tujuan, materi, metode, teknik, media pembelajaran dengan kebutuhan warga belajar. Pelaksanaan kegiatan pembelajarandilakukan sebagai proses transformasi pengetahuan, sikap dan keterampilan dari sumber belajar kepada warga belajar. Pelaksanaan pelatihan dilakukan secara efektif dan efisien, karena sesuai dengan waktu yang dijadwalkan dan menghasilkan lulusan yang diharapkan.

3. Hasil dan Pengaruh Program Pelatihan Keterampilan Fotografi memberikan makna yang positif tehadap perilaku kehidupan mereka, khususnya pada peningkatan pengetahuan dan keterampilan dibidang fotografi serta pengembangan sikap etika fotografer yang akhirnya bermanfaat dalam pengembangan kehidupannya.

4. Tindak lanjut Pasca Pelatihan Keterampilan Fotografi adalah sebagai program lembaga yang telah disusun untuk suatu agenda rutin dalam rangka implementasi Perguruan Tinggi STKIP Siliwangi berkenaan dengan fungsinya Tridarma Perguruan Tinggi, terutama dalam hal Pengabdian terhadap Masyarakat.

\section{B. Saran}

1. Penyelenggara STKIP Siliwangi perlu mengadakan persiapan dan perencanaan yang lebih matang dalam penyelenggaraan program pelatihan, sehingga segala sesuatunya dapat berjalan dengan terukur dan terarah. Berkenaan denga proses penyelenggaraan, penyelenggara perlu melakukan pembenahan agar pelaksanaannya lebih komunikatif terhadap warga belajar.

2. Bagi Instruktur hendaklah melakukan persiapan yang totalitas untuk dapat menyajikan materi secara sempurna sehingga hasil yang didapatkan oleh para peserta pelatihan dapat maksimal. 
3. Bagi alumni lulusan STKIP Siliwangihendaknya tidak berhenti untuk terus mengimplementasikan yang diperolehnya. Selanjutnya, koordinasi dan silaturahim harus tetap dijalin baik diantara sesama alumni, maupun dengan pihak penyelenggara sebagai media konsultasi atau berbagi pengalaman. Karena pengalaman dan tantangan pada masing-masing lapangan tidak bisa sama, sehingga transfer informasi harus terus dijalin

4. Bagi masyarakat luas hendaklah mengetahui dan memahami bahwa berbagai kegiatan pelatihan keterampilan, seperti halnya keterampilan fotografi mempunyai nilai manfaat yang sangat besar, yang dapat dijadikan salah satu solusi untuk pemecahan masalah yang ada dimasyarakat terutama dibidang peningkatan penghasilan dan krisis ekonomi.

\section{DAFTAR PUSTAKA}

Arikunto. S, (2006), Dasar-Dasar Evaluasi Pendidikan. Jakarta: Bumi Aksara

(2008), Dasar-Dasar Evaluasi Pendidikan (Edisi Revisi), PT Bumi Aksara, Jakarta

Arikunto S, dan Rekan, (2007). Evaluasi Program Pendidikan Pedoman Teoritis Praktis bagi Praktisi Pendidikan, PT Bumi Aksara, Jakarta

Depdiknas RI, (2005), Kamus Besar Bahasa Indonesia, Balai Pustaka, Jakarta

(2003), Undang-Undang RI No. 20 Tahun 3003 tentang Sistem Pendidikan Nasional, Jakarta

(2003), Modul Diklat Management of Trainers,
Pusdiklat Pegawai Depdiknas, Sawangan Depok.

Gita Setra, (2007), Himbauan dari dan untuk Lapangan, Jurnal BP-PLSP Regional II Jaya Giri.

Hasan, Engking Soewarman, (2003), Pengelolaan Program Pendidikan Luar Sekolah, Untuk Tugas penyusunan Makalah, SPs, UPI, Bandung

Menciptaka

Bersumber Daya Unggul, Jurusan PLS, FIP, UPI, Bandung.

Safuri Musa (2005). Evaluasi Program. Pembelajaran dan Pemberdayaan Masyarakat. Yayasan Pengkajian Pendidikan Non Formal Indonesia Y-PIN Indonesia. (2006), Evaluasi Program PLS, Untuk Pendidikan Nonformal dan Pengembangan Sumber daya Manusia, PT Remaja Rosdakarya, Bandung.

(2007), Sistem dan Manajemen Pelatihan Teori dan Aplikasi, Falah Production, Bandung.

Trisnamansyah, Sutaryat, (2008), Metode Penelitian Handout Perkuliahan Program Studi Pendidikan Luar Sekolah Program S-2 SPS-UPI, Bandung

https://id.wikipedia.org/wiki/PNPM_M andiri_Pedesaan (13 September 2015) 